\title{
Chemical gastric inhibitory polypeptide receptor antagonism protects against obesity, insulin resistance, glucose intolerance and associated disturbances in mice fed high-fat and cafeteria diets
}

\author{
V. A. Gault • P. L. McClean • R. S. Cassidy • N. Irwin • \\ P. R. Flatt
}

Received: 13 February 2007 / Accepted: 19 April 2007 / Published online: 9 June 2007

(C) Springer-Verlag 2007

\begin{abstract}
Aims/hypothesis Gastric inhibitory polypeptide (GIP) receptor antagonism with $\left(\mathrm{Pro}^{3}\right) \mathrm{GIP}$ improves glucose tolerance and ameliorates insulin resistance and abnormalities of islet structure/function in $o b / o b$ mice. This study examined the ability of $\left(\mathrm{Pro}^{3}\right)$ GIP to counter the development of obesity, insulin resistance and diabetes in mice fed high-fat and cafeteria diets.

Materials and methods Young Swiss TO mice on standard chow or high-fat, cafeteria or high-carbohydrate diets received daily injections of either saline or $\left(\mathrm{Pro}^{3}\right)$ GIP $\left(25 \mathrm{nmol} \mathrm{kg}{ }^{-1} \mathrm{day}^{-1}\right)$ over 16 weeks. Food intake, body weight, and circulating glucose and insulin were measured frequently. At 16 weeks, glucose tolerance, insulin sensitivity, $\mathrm{HbA}_{1 \mathrm{c}}$, circulating hormones and plasma lipids were assessed. Adipose tissue, liver and muscle were excised and weighed, and their histology and triacylglycerol content were further examined.

Results $\left(\mathrm{Pro}^{3}\right)$ GIP significantly reduced body weight, enhanced locomotor activity, and improved $\mathrm{HbA}_{1 \mathrm{c}}$, glucose tolerance, beta cell responsiveness and insulin sensitivity in mice fed high-fat and cafeteria diets $(p<0.05$ to $p<0.01)$. Similarly, $\left(\mathrm{Pro}^{3}\right)$ GIP significantly reduced plasma corticosterone and triacylglycerols $(p<0.05$ to $p<0.001)$, while glucagon, resistin and adiponectin were unchanged. $\left(\mathrm{Pro}^{3}\right)$ GIP decreased adipose tissue mass $(p<0.01)$ and the triacylglycerol content of liver, muscle and adipose tissue
\end{abstract}

\footnotetext{
V. A. Gault • P. L. McClean • R. S. Cassidy $\cdot$ N. Irwin $(\varangle) \cdot$

P. R. Flatt

School of Biomedical Sciences, University of Ulster,

Cromore Road,

Coleraine, Northern Ireland BT52 1SA, UK

e-mail: n.irwin@ulster.ac.uk
}

$(p<0.01$ to $p<0.001)$. Adipocyte size and liver morphology were partially normalised. (Pro ${ }^{3}$ )GIP did not significantly affect any of these parameters in mice fed a highcarbohydrate diet.

Conclusions/interpretation ( Pro $^{3}$ )GIP protects against obesity, insulin resistance, glucose intolerance and associated disturbances in mice fed high-fat and cafeteria diets. This highlights chemical GIP receptor antagonism as a new possibility for the treatment of obesity and associated metabolic disturbances.

Keywords Diet-induced obesity - Gastric inhibitory polypeptide - Gastric inhibitory polypeptide antagonist . Insulin resistance $\cdot$ Obesity-related diabetes $\cdot\left(\mathrm{Pro}^{3}\right) \mathrm{GIP}$
Abbreviations
AAC area above the curve
GIP gastric inhibitory polypeptide

\section{Introduction}

An epidemic of diabetes is poised to afflict affluent and developing societies throughout the world, fuelled by ageing demographics and the recent explosion of obesity and related insulin resistance that now sees increasing numbers of children presenting with type 2 diabetes [1]. Obesity is associated with the 'metabolic syndrome', characterised by insulin resistance, glucose intolerance, hypertension, dyslipidaemia and atherosclerosis. Without intervention, this will lead to full-blown type 2 diabetes, severely eroding quality of life and greatly reducing life expectancy. Therefore, novel approaches which aim to 
improve the responsiveness of peripheral tissues to insulin and aid restraint of rising obesity are of important therapeutic interest. Despite its classic role as an insulinreleasing intestinal hormone, recent data indicate that gastric inhibitory polypeptide (GIP) exerts effects on adipose tissue and lipid metabolism to promote fat deposition and insulin resistance [2,3]. There is now accumulating evidence to suggest a possible role for GIP receptor antagonists in the alleviation of obesity and insulin resistance $[4,5]$.

Although involvement of GIP in the aetiology and metabolic disturbances of obesity has long been suspected, this aspect has been very largely overlooked due to its greater recognition as an important entero-insular hormone and glucose-dependent stimulator of insulin secretion [3, 68]. Nevertheless, data gathered over time plus more recent observations provide quite compelling evidence that GIP is a key link between consumption of affluent energy-rich high-fat diets and causation of insulin resistance, obesity and type 2 diabetes $[4,5]$.

Many pieces of indirect evidence support the involvement of GIP in obesity and its various manifestations. First, ingestion of fat has very strong and protracted stimulatory effects on GIP secretion that greatly exceed effects of ingested carbohydrate and protein [9]. Second, consumption of a high-fat diet results in $\mathrm{K}$ cell hyperplasia, increased GIP gene expression and intestinal GIP, resulting in increased circulating GIP concentrations [10-13]. Animal models and humans with obesity diabetes have been reported also to exhibit elevated circulating GIP and exaggerated $\mathrm{K}$ cell secretory responses [14-16]. At the cellular level, GIP receptors have been demonstrated on adipocytes [17]. These mediate various anabolic effects of GIP, including stimulation of glucose uptake, lipoprotein lipase activity, fatty acid synthesis and fatty acid incorporation into adipose tissue [18-21]. At the same time, GIP inhibits both glucagon- and isoproterenol-induced lipolysis, thereby further favouring deposition rather than mobilisation of fat stores [22, 23]. Consistent with these various observations, both normal and obese diabetic $o b / o b$ mice with genetic knockout of the GIP receptor are protected from diet-induced obesity [2].

Chemical ablation of GIP signalling using a specific GIP receptor antagonist, $\left(\mathrm{Pro}^{3}\right) \mathrm{GIP}$, in obese diabetic $o b / o b$ mice has unequivocally demonstrated how GIP receptor antagonism can provide a novel approach to the treatment and prevention of obesity-related diabetes [4, 24]. In the present study, we have investigated the ability of $\left(\mathrm{Pro}^{3}\right)$ GIP to counter the development of obesity, insulin resistance and diabetes in mice fed high-fat and cafeteria diets. An additional group fed a high-carbohydrate diet was employed to examine the importance of nutritional energy source.

\section{Materials and methods}

Animals and diet regimens Male NIH Swiss mice at 68 weeks were obtained from Harlan UK (Shaw's Farm, Blackthorn, UK). Animals were age-matched, divided into groups and housed individually in an air-conditioned room at $22 \pm 2^{\circ} \mathrm{C}$ with a $12 \mathrm{~h}$ light: $12 \mathrm{~h}$ darkness cycle $(08: 00$ 20:00 hours). Control animals received a standard rodent maintenance diet composed of $10 \%$ fat, $30 \%$ protein and $60 \%$ carbohydrate ad libitum (percentage total energy of $12.99 \mathrm{~kJ} / \mathrm{g}$; Trouw Nutrition, Northwich, UK). The high-fat diet was composed of $45 \%$ fat, $20 \%$ protein and $35 \%$ carbohydrate $(26.15 \mathrm{~kJ} / \mathrm{g}$; Special Diet Services, Witham, UK), and was available ad libitum to mice in this group, referred to as 'high-fat mice' throughout the remainder of this article. Cafeteria-fed animals, referred to as 'cafeteria mice', received standard rodent maintenance diet ad libitum $(12.99 \mathrm{~kJ} / \mathrm{g}$; Trouw Nutrition) alongside a 6 day rotation of the following food pairs: tuna fish and Pringles; peanut butter and chocolate digestives; Madeira cake and milk chocolate; cereal and luncheon meat; sausages and corned beef; and cheese and marzipan. The overall composition of the cafeteria diet consumed during the study period was $34 \%$ fat, $18 \%$ protein and $48 \%$ carbohydrate $(23.74 \mathrm{~kJ} / \mathrm{g})$. The high-carbohydrate diet was composed of $10 \%$ fat, $20 \%$ protein and $70 \%$ carbohydrate $(18.8 \mathrm{~kJ} / \mathrm{g}$; Special Diet Services), and was available ad libitum to mice in this group, referred to as 'high-carbohydrate mice'. Drinking water was freely available to all groups of animals. All animal experiments were carried out in accordance with the UK Animals (Scientific Procedures) Act 1986.

Experimental protocols for in vivo studies Over a 16 week period, dietary-intervention animals received once-daily i.p. injections (17:00 hours) of either saline vehicle $(0.9 \%[w / v]$ $\mathrm{NaCl})$ or $\left(\mathrm{Pro}^{3}\right) \mathrm{GIP}(25 \mathrm{nmol} / \mathrm{kg}$ body weight; SigmaGenosys, Cambridge, UK). Control animals received once-daily i.p. injections of saline. Food intake and body weight were recorded every 3-4 days for all groups, except the cafeteria fed animals, which were recorded daily. Plasma glucose and insulin concentrations were monitored at weekly intervals. Blood for the measurement of $\mathrm{HbA}_{1 \mathrm{c}}$ and plasma for measurement of cholesterol, triacylglycerols, glucagon, corticosterone, adiponectin and resistin were taken on week 16. Intraperitoneal glucose tolerance $(18 \mathrm{mmol} / \mathrm{kg}$ body weight) and insulin sensitivity (50 U/kg body weight) tests were performed at the end of the study period. All acute experiments commenced at 10:00 hours. In a separate series, pancreatic tissues were excised at the end of the 16 week treatment period, weighed and processed for measurement of insulin following extraction with $5 \mathrm{ml} / \mathrm{g}$ of ice-cold acid ethanol (750 ml ethanol, $235 \mathrm{ml}$ water, $15 \mathrm{ml} 12 \mathrm{~mol} / \mathrm{l} \mathrm{HCl})$. Brown adipose tissue, white adipose tissue (epididymal, peri- 
renal and subcutaneous), liver and skeletal muscle were also excised, weighed and stored for histology or measurement of triacylglycerol content. In a final set of experiments, locomotor activity tests were performed in high-fat mice after 4 weeks of treatment with either $\left(\operatorname{Pro}^{3}\right)$ GIP or saline, as assessed from total distance traversed in an open field $(120 \times 120 \mathrm{~cm}$ surface area with $35 \mathrm{~cm}$ high walls), calculated from measurement of line breaks $(15 \times 15 \mathrm{~cm}$ grid). Animals were given $3 \mathrm{~min}$ each in the arena and tested over 5 days [25].

Biochemical analysis Blood samples taken from the cut tip of the tail vein of conscious mice at the times indicated in the figures were immediately centrifuged using a Beckman microcentrifuge (Beckman Instruments, High Wycombe, $\mathrm{UK})$ for $30 \mathrm{~s}$ at $13,000 \times g$. The resulting plasma was then aliquoted into fresh Eppendorf tubes and stored at $-20^{\circ} \mathrm{C}$ prior to analysis. Plasma glucose was assayed by an automated glucose oxidase procedure [26] using a Beckman Glucose Analyser II (Beckman Instruments, Galway, Ireland). Plasma and pancreatic insulin were assayed by a modified dextran-coated charcoal RIA [27]. $\mathrm{HbA}_{1 c}$ was determined using a commercially available kit purchased from Chirus (Watford, UK). Plasma and tissue triacylglycerol and cholesterol levels were measured using a Hitachi Automated Analyser 912 (Boehringer, Mannheim, Germany). Serum glucagon and plasma adiponectin and resistin concentrations were measured using RIA kits purchased from Linco Research (St Charles, MI, USA). Corticosterone concentrations were similarly measured using a kit supplied by MP Biomedicals (Heidelberg, Germany). All analyses were carried out according to instructions supplied by the various manufacturers. Lipid and protein contents of extracted tissues were measured as described previously [28]. Protein was determined using a Dc Protein Kit (Bio-Rad, Hercules, CA, USA).
Fig. 1 Effects of daily $\left(\mathrm{Pro}^{3}\right)$ GIP administration on energy intake (a-c) and body weight (d-f) of mice fed high-fat (a, d), cafeteria $(\mathbf{b}, \mathbf{e})$ and highcarbohydrate (c, f) diets. Parameters were measured at 3-4 day intervals during the 16 week treatment period. Control animals received a standard rodent maintenance diet. The composition of the various diets fed ad libitum is given in the "Materials and methods" section. Each diet group received once-daily i.p. injections of $\left(\mathrm{Pro}^{3}\right) \mathrm{GIP}(25 \mathrm{nmol} / \mathrm{kg}$ body weight) or saline for 16 weeks. Squares, control saline; circles, dietary intervention; triangles, dietary intervention $+\left(\mathrm{Pro}^{3}\right)$ GIP. Control animals received daily saline injections. Values are means \pm SEM of nine mice. ${ }^{*} p<0.05,{ }^{*} p<0.01$, $* * * p<0.001$ compared with control group; ${ }^{\Delta} p<0.05$, $\Delta \Delta p<0.01, \Delta \Delta \Delta p<0.001$ compared with $\left(\mathrm{Pro}^{3}\right)$ GIPtreated group a

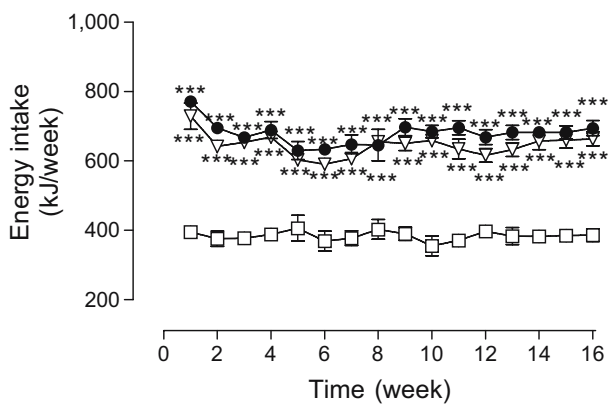

C

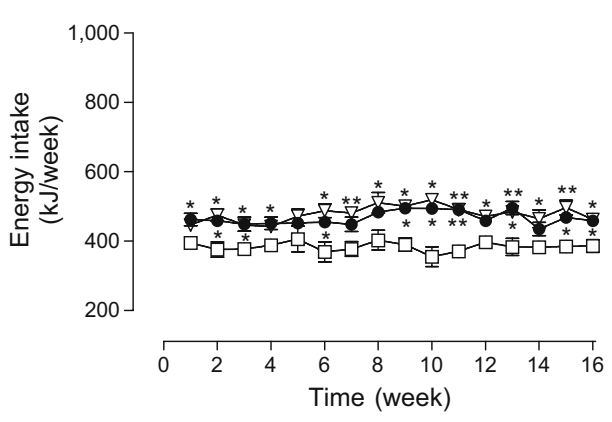

e

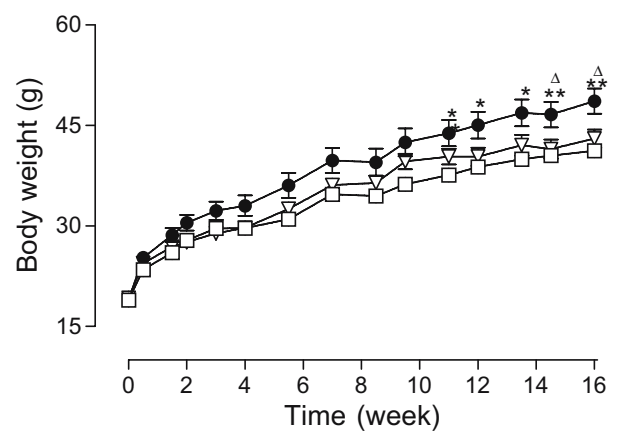

b

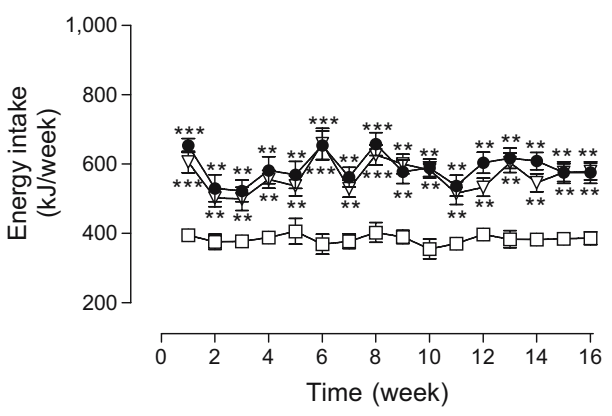

d

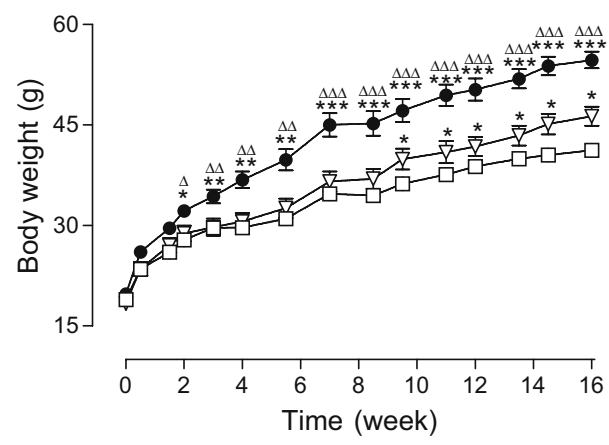

f

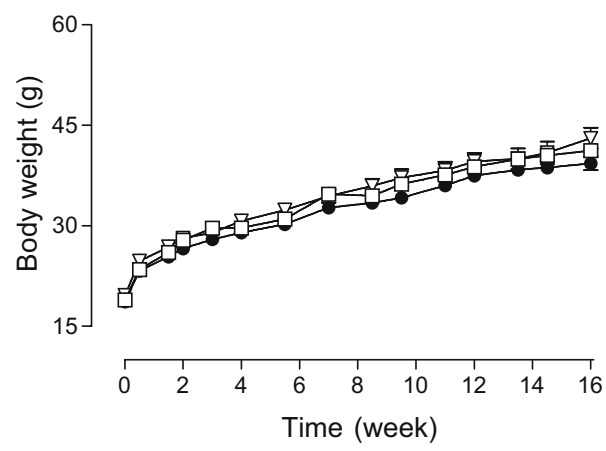


Histology Excised white adipose tissue and liver were fixed in $4 \%(w / v)$ paraformaldehyde/PBS and embedded in paraffin. Sections $(8 \mu \mathrm{m})$ were cut and mounted on slides as described elsewhere [4]. White adipose tissue was stained with haematoxylin and counterstained with eosin, while liver was stained with Oil Red $\mathrm{O}$ and counterstained with haematoxylin. Stained slides were viewed under a microscope (Nikon Eclipse E2000; Diagnostic Instruments, Sterling Heights, MI, USA) attached to a JVC camera Model KY-F55B (JVC, London, UK).

Statistical analysis Results are expressed as means \pm SEM. Data were compared using ANOVA, followed by a Student-Newman-Keuls post hoc test. AUC analyses were calculated using the trapezoidal rule with baseline subtrac- tion [29]. A $p$ value of less than 0.05 was considered to be statistically significant.

\section{Results}

Effects of $\left(\mathrm{Pro}^{3}\right)$ GIP on food intake, body weight, nonfasting plasma glucose and insulin and $H b A_{1 c}$ concentrations Food intake over 16 weeks was consistently greater in the high-fat, cafeteria and high-carbohydrate groups $(99.1 \pm 3.1,94.8 \pm 2.9$ and $64.3 \pm 2.7 \mathrm{~kJ}$ per mouse per day; $p<0.05$ to $p<0.001$, respectively) compared with saline controls (55.2 $\pm 2.6 \mathrm{~kJ}$ per mouse per day; Fig. 1a-c). In the high-fat and cafeteria groups, this was associated with progressively increased body weights (Fig. 1d,e).
Fig. 2 Effects of daily $\left(\mathrm{Pro}^{3}\right)$ GIP administration on non-fasting plasma glucose and $\mathrm{HbA}_{1 \mathrm{c}}$ concentrations $(\mathbf{a}-\mathbf{c})$ and insulin concentrations $(\mathbf{d}-\mathbf{f})$ of mice fed high-fat (a, d), cafeteria $(\mathbf{b}, \mathbf{e})$ and high-carbohydrate (c, f) diets. Plasma glucose and insulin concentrations were measured weekly during daily treatment with $\left(\mathrm{Pro}^{3}\right)$ GIP ( $25 \mathrm{nmol} / \mathrm{kg}$ body weight) or saline for 16 weeks. Squares, control saline; circles, dietary intervention; triangles, dietary intervention $+\left(\mathrm{Pro}^{3}\right)$ GIP. For $\mathrm{HbA}_{1 \mathrm{c}}$ : open bars, control saline; filled bars, dietary intervention; striped bars, dietary intervention $+\left(\mathrm{Pro}^{3}\right)$ GIP. Values are means \pm SEM of nine mice. ${ }^{*} p<0.05,{ }^{* *} p<0.01$, $* * * p<0.001$ compared with control group; ${ }^{\Delta} p<0.05$ compared with $\left(\mathrm{Pro}^{3}\right)$ GIP-treated group
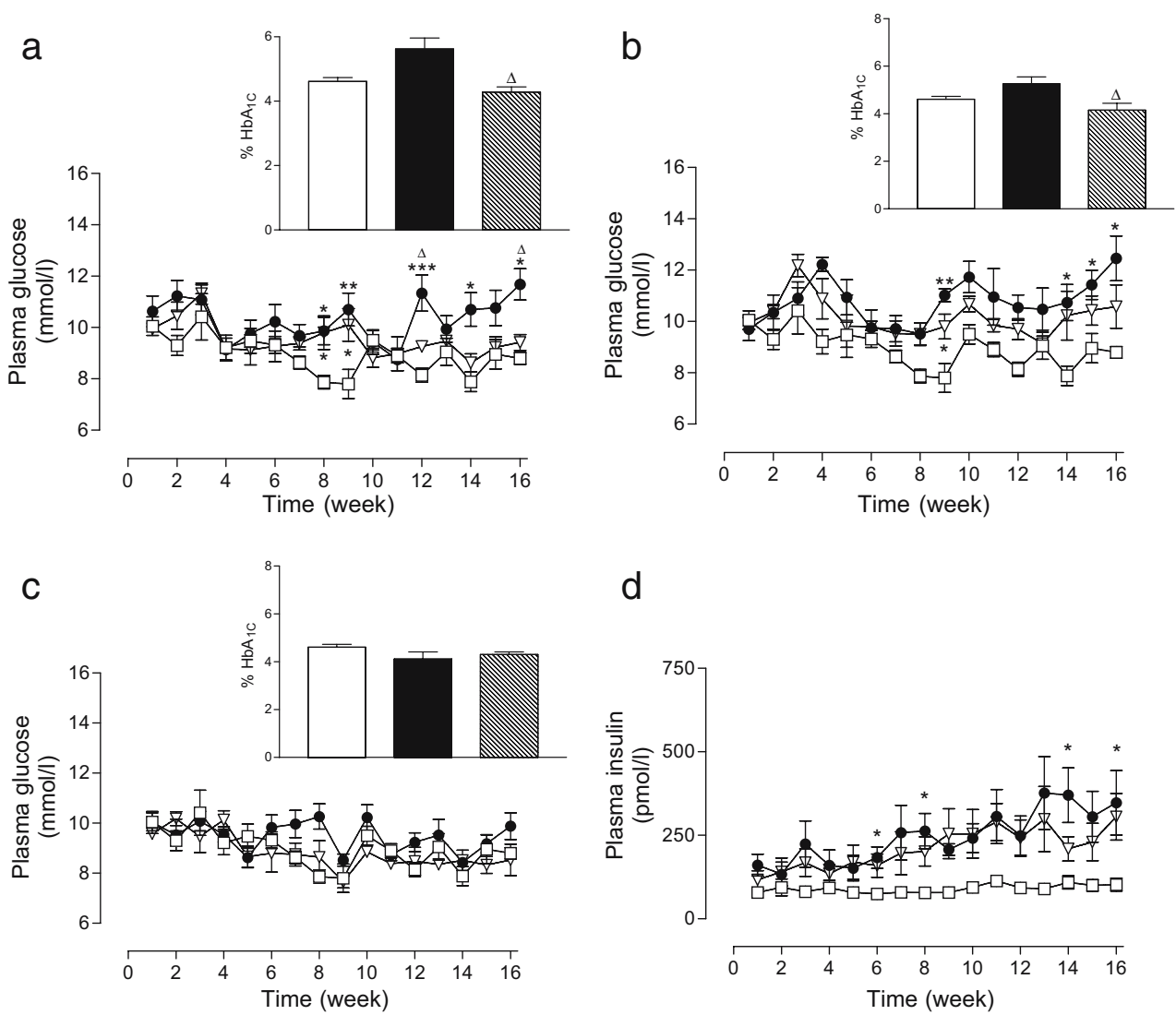

d

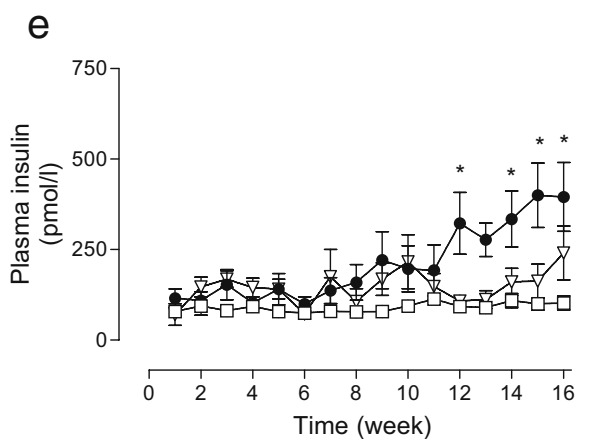

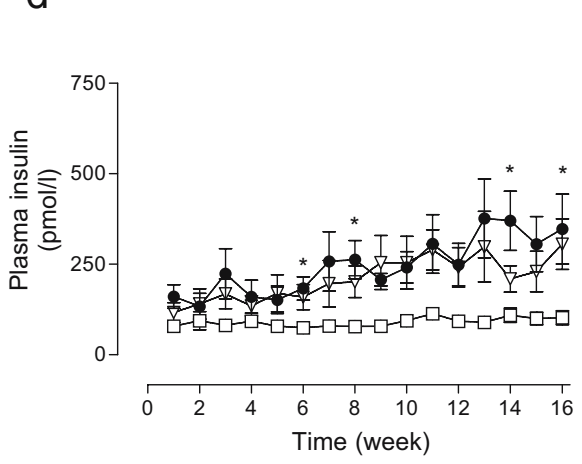

f

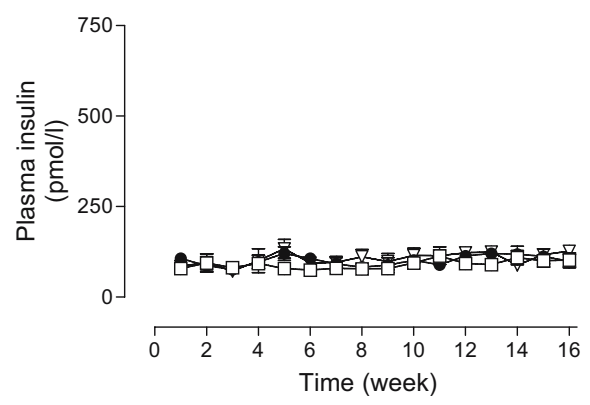


Final body weights of these mice were $55.0 \pm 1.2$ and $49.2 \pm$ $1.8 \mathrm{~g}$, respectively, compared with $41.5 \pm 0.9 \mathrm{~g}$ for control animals $(p<0.01$ to $p<0.001)$. Administration of $\left(\mathrm{Pro}^{3}\right) \mathrm{GIP}$ had no effect on food intake in any of the groups (Fig. 1a-c). $\left(\mathrm{Pro}^{3}\right)$ GIP treatment of high-fat and cafeteria mice significantly reduced body weight, corresponding to decreases of $15.4 \%$ and $11.5 \%$, respectively, compared with controls $(p<$ 0.05 to $p<0.001$; Fig. $1 \mathrm{~d}$,e). Administration of $\left(\mathrm{Pro}^{3}\right)$ GIP to high-carbohydrate mice had no effect on body weight (Fig. 1f). As shown in Fig. 2a,b, mice on high-fat and cafeteria diets exhibited significantly raised plasma glucose concentrations compared with controls $(p<0.05$ to $p<0.001)$. On week 12, high-fat mice receiving $\left(\mathrm{Pro}^{3}\right)$ GIP exhibited significantly reduced glucose concentrations $(p<0.05$; Fig. 2a). While there was a general trend for reduced plasma glucose in $\left(\mathrm{Pro}^{3}\right)$ GIP-treated cafeteria mice, this failed to reach significance (Fig. 2b). In contrast, there were no observed differences in plasma glucose concentrations between both groups of high-carbohydrate mice and saline controls (Fig. 2c). Consistent with the observed pattern in
Fig. 3 Effects of daily $\left(\mathrm{Pro}^{3}\right)$ GIP administration on glucose tolerance $(\mathbf{a}-\mathbf{c})$ and plasma insulin response $(\mathbf{d}-\mathbf{f})$ to glucose in mice fed high-fat $(\mathbf{a}, \mathbf{d})$, cafeteria (b, e) and high-carbohydrate $(\mathbf{c}, \mathbf{f})$ diets. Tests were conducted after daily treatment with $\left(\right.$ Pro $\left.^{3}\right)$ GIP $(25 \mathrm{nmol} / \mathrm{kg}$ body weight) or saline for 16 weeks. Squares, control saline; circles, dietary intervention; triangles, dietary intervention $+\left(\mathrm{Pro}^{3}\right)$ GIP. Glucose

(18 $\mathrm{mmol} / \mathrm{kg}$ body weight) was administered by i.p. injection at the time indicated by the arrow. Plasma glucose and insulin values together with overall plasma AUC values for $0-105 \mathrm{~min}$ after injection are shown. Open bars, control saline; filled bars, dietary intervention; striped bars, dietary intervention $+\left(\mathrm{Pro}^{3}\right)$ GIP. Values are means \pm SEM for nine mice. ${ }^{*} p<0.05, * * p<0.01$, $* * * p<0.001$ compared with control group; ${ }^{\Delta} p<0.05$, $\Delta \Delta p<0.01$ and $\Delta \Delta \Delta_{p}<0.001$ compared with $\left(\mathrm{Pro}^{3}\right)$ GIPtreated group
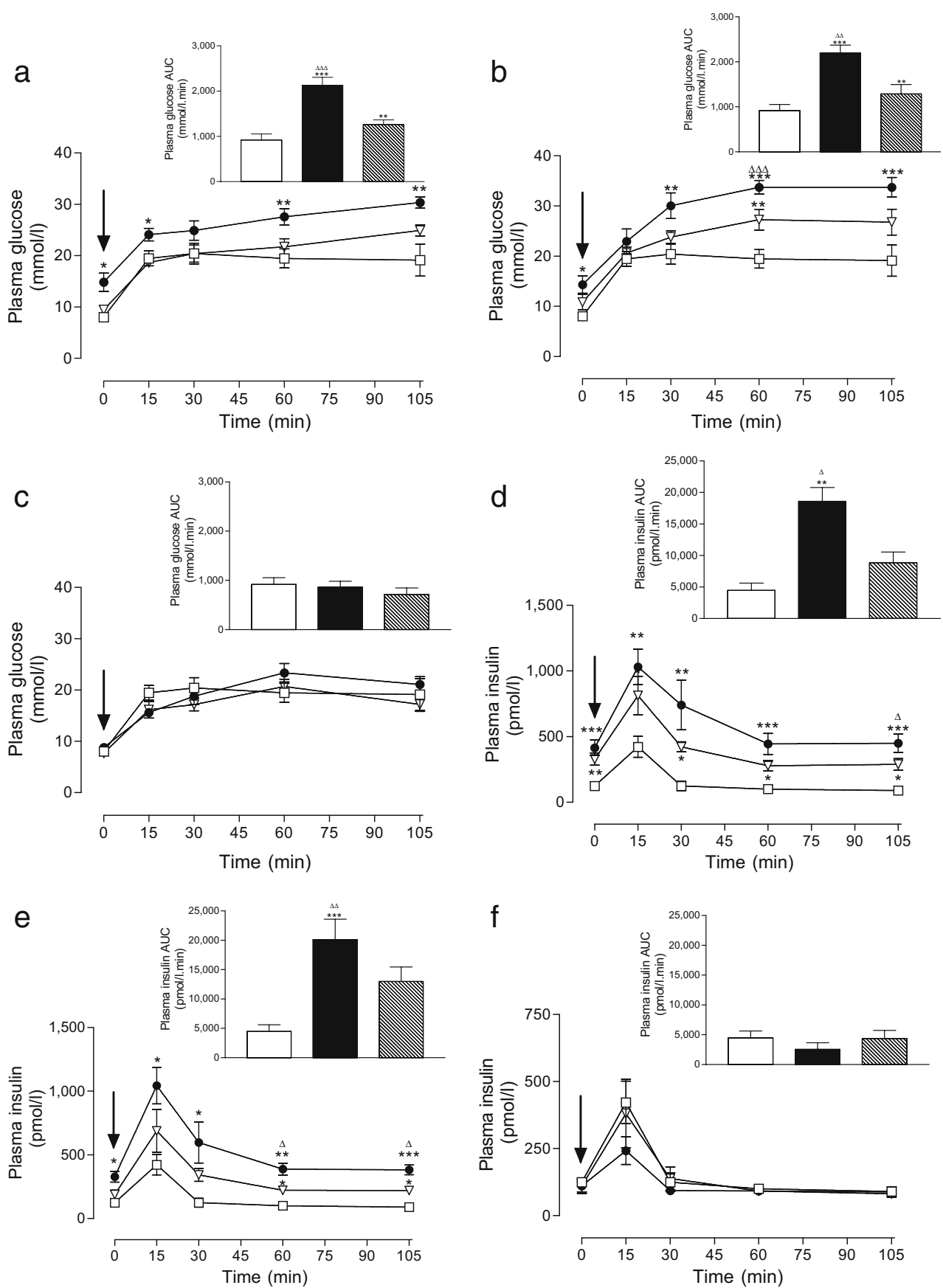
plasma glucose, $\mathrm{HbA}_{1 \mathrm{c}}$ was significantly lower (1.2-fold; $p<$ $0.05)$ in both high-fat $(4.2 \pm 0.1 \%)$ and cafeteria mice $(4.1 \pm$ $0.2 \%$ ) after 16 weeks of treatment with $\left(\mathrm{Pro}^{3}\right)$ GIP compared with control animals (5.2 $\pm 0.2 \%)$ (Fig. $2 \mathrm{a}-\mathrm{c}$, insets). No significant changes in plasma insulin levels were noted in any of the diet groups, although both high-fat and cafeteria mice exhibited hyperinsulinaemia $(p<0.05$ to $p<0.01)$ compared with saline controls (Fig. 2d-f).

Effects of $\left(\right.$ Pro $\left.^{3}\right)$ GIP on glucose tolerance High-fat and cafeteria mice, but not high-carbohydrate mice, exhibited impaired glucose tolerance and impaired insulin response to i.p. glucose at 16 weeks (Fig. 3). Daily administration of $\left(\right.$ Pro $\left.^{3}\right)$ GIP resulted in significantly reduced plasma glucose concentrations in high-fat and cafeteria mice following the glucose challenge $\left(\mathrm{AUC}_{0-105}\right.$ value 1.7-fold lower; $p<0.01$; Fig. 3a,b). Similarly, corresponding plasma insulin concentrations were significantly decreased $\left(\mathrm{AUC}_{0-105}\right.$ value 2.1 and 1.6-fold lower, respectively; $p<0.05$ to $p<0.01$;
Fig. 3d,e). Treatment of high-carbohydrate mice with $\left(\right.$ Pro $\left.^{3}\right)$ GIP for 16 weeks had no significant effects on plasma glucose or insulin concentrations following i.p. glucose (Fig. 3c,f).

Effects of $\left(\mathrm{Pro}^{3}\right)$ GIP on insulin sensitivity and pancreatic insulin content Unlike mice on the high-carbohydrate diet, mice fed a high-fat or cafeteria diet exhibited insulin resistance at 16 weeks, as illustrated by impaired glucose lowering in response to exogenous insulin (Fig. 4). Daily treatment with $\left(\right.$ Pro $^{3}$ )GIP significantly augmented the hypoglycaemic action of insulin in high-fat and cafeteria mice in terms of post-injection values $(p<0.05$ to $p<0.001$; Fig. 4a,c) and area above the curve (AAC) measures $\left(\mathrm{AAC}_{0-90}\right.$ value 1.7-fold lower; $p<0.01$; Fig. 4b,d). Daily administration of ( Pro $^{3}$ )GIP for 16 weeks had no significant effects on insulin sensitivity in high-carbohydrate mice (Fig. 4e,f). ( Pro $^{3}$ )GIP treatment significantly decreased pancreatic insulin content in high-fat $(0.20 \pm 0.03$ vs $0.33 \pm$
Fig. 4 Effects of daily (Pro $\left.{ }^{3}\right)$ GIP administration on insulin sensitivity in mice fed high-fat $(\mathbf{a}, \mathbf{d})$, cafeteria $(\mathbf{b}, \mathbf{e})$ and highcarbohydrate $(\mathbf{c}, \mathbf{f})$ diets. Tests were conducted after daily treatment with $\left(\mathrm{Pro}^{3}\right) \mathrm{GIP}$ ( $25 \mathrm{nmol} / \mathrm{kg}$ body weight) or saline for 16 weeks. Open squares, control saline; solid circles, dietary intervention; open inverted triangles, dietary intervention $+\left(\mathrm{Pro}^{3}\right)$ GIP. Insulin (50 U/kg body weight) was administered by i.p. injection at the time indicated by the arrow. a-c Glucose data as a percentage of basal values. d-f AAC values for 0-90 min after injection. Open bars, control saline; filled bars, dietary intervention; striped bars, dietary intervention+ $\left(\mathrm{Pro}^{3}\right)$ GIP. Values are means \pm SEM for nine mice. ${ }^{*} p<0.05$, $* * p<0.01$ and $* * * p<0.001$ compared with control group; ${ }^{\Delta} p<0.05,{ }^{\Delta \Delta} p<0.01$,

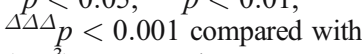
$\left(\mathrm{Pro}^{3}\right)$ GIP-treated group a

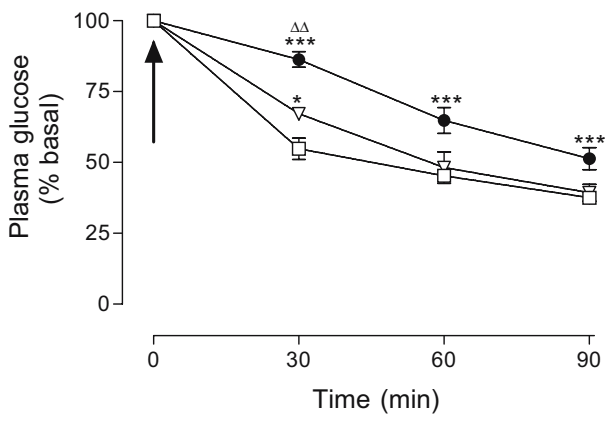

b

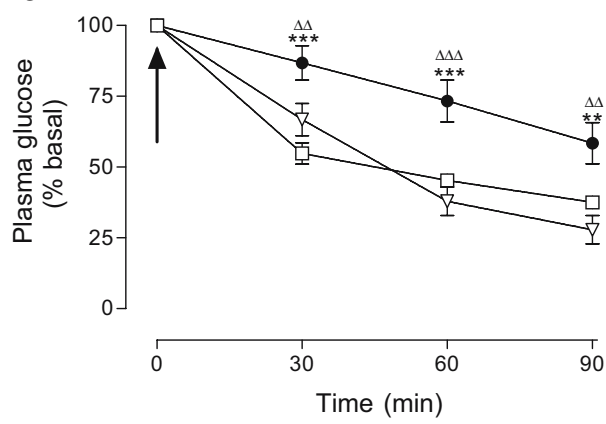

C

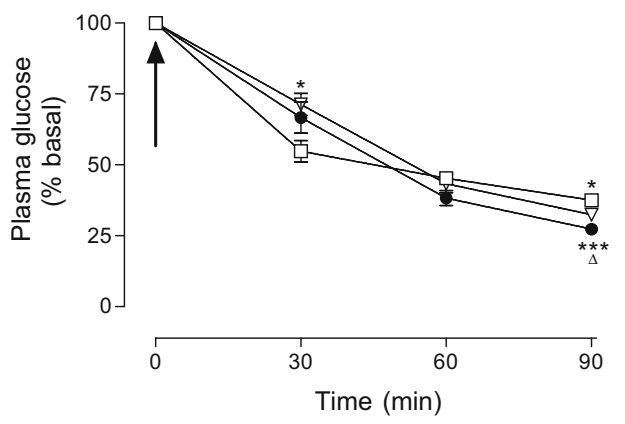

d

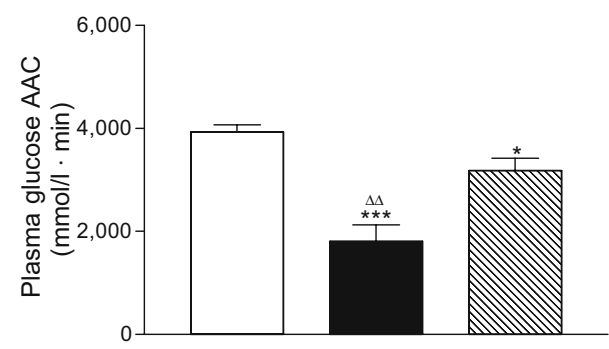

e

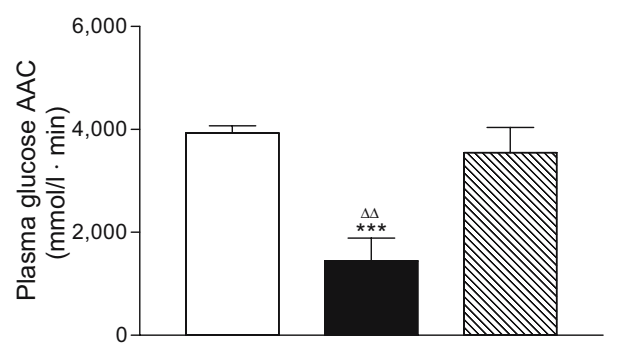

f

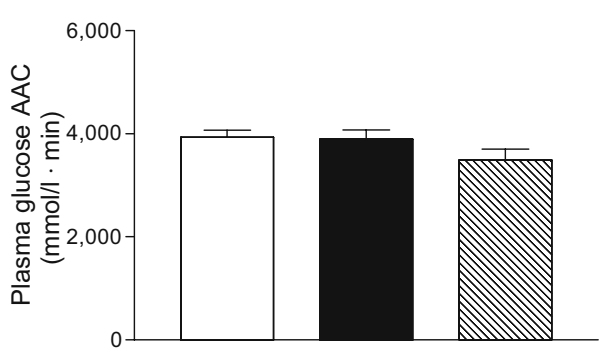


$0.05 \mu \mathrm{mol} / \mathrm{g}$ tissue; $p<0.01)$ and cafeteria mice $(0.13 \pm 0.03$ vs $0.19 \pm 0.04 \mu \mathrm{mol} / \mathrm{g}$ tissue; $p<0.05$ ). The insulin content of both groups of high-carbohydrate mice $(0.34 \pm 0.03$ vs $0.37 \pm$ $0.04 \mu \mathrm{mol} / \mathrm{g}$ ) did not differ from that of control animals. All pancreatic weights were similar (data not shown).

Effects of $\left(\mathrm{Pro}^{3}\right)$ GIP on circulating glucagon, corticosterone, adiponectin, resistin and lipid profile Compared with appropriate untreated controls, daily administration of $\left(\mathrm{Pro}^{3}\right)$ GIP did not significantly affect serum glucagon concentrations in any of the diet groups (Fig. 5a). Daily $\left(\mathrm{Pro}^{3}\right)$ GIP treatment significantly reduced plasma corticosterone concentrations in high-fat $(3.0$-fold lower; $p<0.001)$ and cafeteria mice $(1.5$-fold lower; $p<0.05)$ but did not significantly affect plasma corticosterone in high-carbohydrate mice (Fig. 5b). Untreated high-fat mice were the only group to show significantly raised ( 3 -fold; $p<0.001$ ) corticosterone concentrations compared with controls (Fig. 5b). Daily administration of $\left(\mathrm{Pro}^{3}\right) \mathrm{GIP}$ did not significantly alter circulating concentrations of plasma adiponectin and resistin (Fig. 5c,d). Circulating triacylglycerols and total cholesterol were increased in both high-fat (1.4- to 1.6-fold; $p<0.05$ to $p<0.001)$ and cafeteria mice (1.3- to 1.6 -fold; $p<0.05$ to $p<0.01)$ (Fig. 6a,b). ( Pro $\left.^{3}\right)$ GIP significantly $(p<0.05)$ decreased plasma triacylglycerol in both groups as well as lowering cholesterol in high-fat animals. HDL-cholesterol concentrations were unchanged, and high-carbohydrate mice did not display any changes in lipid parameters (Fig. 6).

Effects of $\left(\right.$ Pro $\left.^{3}\right)$ GIP on adipose mass, tissue triacylglycerols and morphology of white adipose tissue and liver Both groups of mice receiving a high-fat or cafeteria diet exhibited increased adipose tissue mass as indicated by total resected tissue weight (Fig. 7a). Treatment with $\left(\mathrm{Pro}^{3}\right)$ GIP significantly decreased (1.1- to 1.3 -fold; $p<0.05$ to $p<$ 0.01 ) fat stores in both high-fat and cafeteria mice but did not affect the normal adipose tissue weight in the highcarbohydrate group (Fig. 7a). These effects in high-fat and cafeteria mice were accompanied by parallel changes in adipocyte size as illustrated for the former group (Fig. 7b). The high-fat animals also exhibited increased triacylglycerol content of liver, muscle and adipose tissue. This was consistently decreased by $\left(\mathrm{Pro}^{3}\right)$ GIP administration (1.5- to 3 -fold; $p<0.01$ to $p<0.001$; Fig. $7 \mathrm{c}$ ). $\left(\right.$ Pro $\left.^{3}\right)$ GIP also partially restored normal liver morphology in the high-fat group (Fig. 7d).

Effects of $\left(\right.$ Pro $\left.^{3}\right)$ GIP on locomotor activity High-fat feeding had no significant effect on physical activity compared with a control diet $(54.8 \pm 2.4$ vs $54.0 \pm 3.6$ line breaks per min, $n=9$, respectively). However, mice treated with $\left(\mathrm{Pro}^{3}\right) \mathrm{GIP}$ exhibited significantly greater locomotor activity $(67.1 \pm 3.0$ line breaks per min) compared with mice on the regular or high-fat diet $(p<0.05)$. The body weight of the $\left(\mathrm{Pro}^{3}\right)$ GIPtreated group was also significantly decreased at this time.

\section{Discussion}

In the present study, normal mice were given free access to two types of high-fat diet, one comprising a synthetic
Fig. 5 Effects of daily $\left(\mathrm{Pro}^{3}\right)$ GIP administration on circulating glucagon (a), corticosterone (b), adiponectin (c) and resistin (d) in mice fed high-fat, cafeteria and high-carbohydrate diets. Parameters were measured after daily treatment with $\left(\mathrm{Pro}^{3}\right)$ GIP ( $25 \mathrm{nmol} / \mathrm{kg}$ body weight) or saline for 16 weeks. Open bars, control saline; filled black bars, high fat; diagonal striped bars, high fat $+\left(\mathrm{Pro}^{3}\right) \mathrm{GIP}$; filled grey bars, cafeteria; horizontal striped bars, cafeteria $+\left(\mathrm{Pro}^{3}\right)$ GIP; vertical striped bars, high carbohydrate; hatched bars, carbohydrate $+\left(\mathrm{Pro}^{3}\right)$ GIP. Values are means \pm SEM for nine mice. $* * * p<0.001$ compared with control group; ${ }^{\Delta} p<0.05$, $\Delta \Delta \Delta p<0.001$, compared with $\left(\right.$ Pro $\left.^{3}\right)$ GIP-treated group a

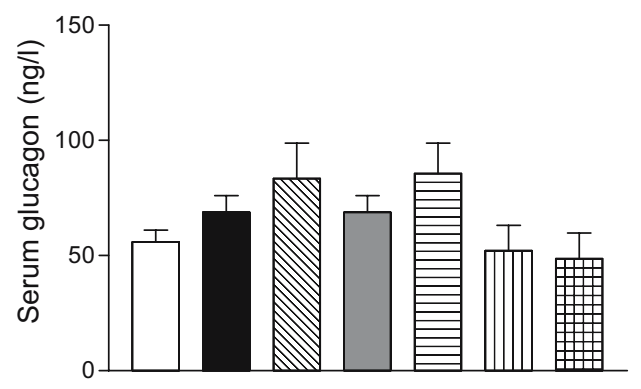

C

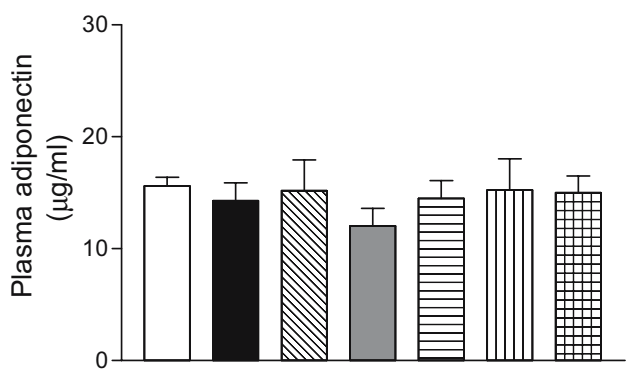

b

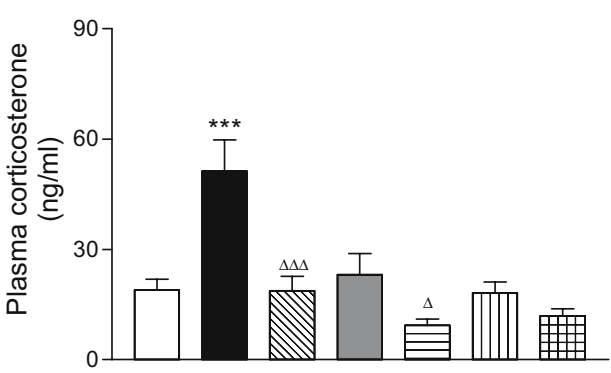

d

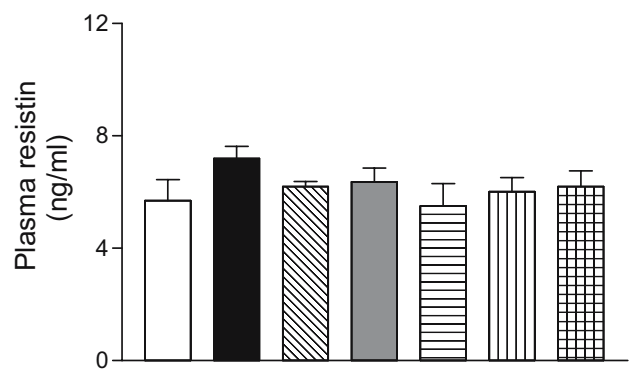


a

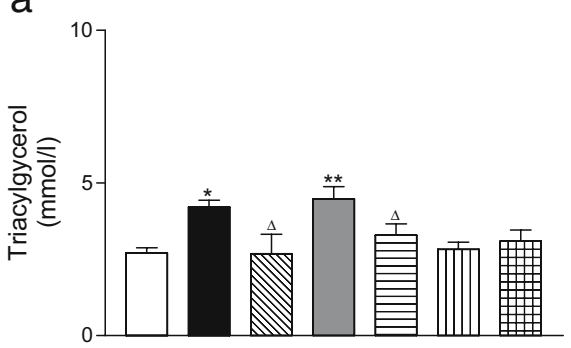

b

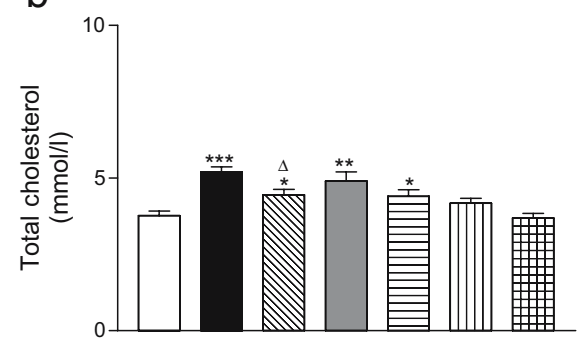

C

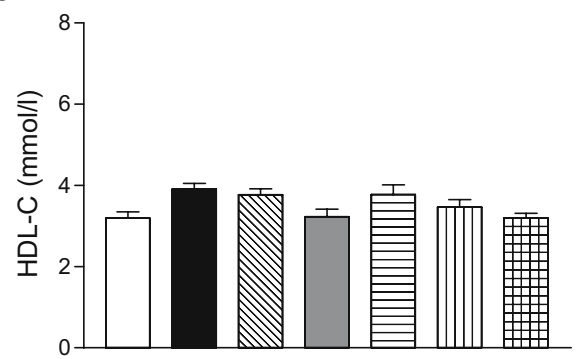

Fig. 6 Effects of daily $\left(\mathrm{Pro}^{3}\right)$ GIP administration on circulating triacylglycerol (a), cholesterol (b) and HDL-cholesterol (HDL-C) (c) in mice fed high-fat, cafeteria and high-carbohydrate diets. Parameters were measured after daily treatment with $\left(\mathrm{Pro}^{3}\right)$ GIP $(25 \mathrm{nmol} / \mathrm{kg}$ body weight) or saline for 16 weeks. Open bars, control saline; filled black bars, high fat; diagonal striped bars, high fat $+\left(\mathrm{Pro}^{3}\right) \mathrm{GIP}$; filled grey bars, cafeteria, horizontal striped bars, cafeteria+( Pro $\left.^{3}\right)$ GIP; vertical striped bars, high carbohydrate; hatched bars, carbohydrate $+\left(\operatorname{Pro}^{3}\right)$ GIP. Values are means \pm SEM for nine mice. ${ }^{*} p<0.05,{ }^{* *} p<0.01,{ }^{* * *} p<$ 0.001 compared with control group; ${ }^{\Delta} p<0.05$ compared with $\left(\mathrm{Pro}^{3}\right)$ GIP-treated group

nutrient mix, and another made up of pairs of various cafeteria items presented in rotation. Such diets have been shown previously to result in increased intestinal and circulating GIP $[10,13,30]$. Consistent with these earlier observations, access to the high-fat diets resulted in increased food (energy) intake, progressive body weight gain, hyperglycaemia and hyperinsulinaemia with notable impairments of glucose tolerance, insulin secretion and insulin sensitivity at 16 weeks. At this time, the animals were visibly obese and exhibited elevated circulating concentrations of cholesterol and triacylglycerol. Adipose tissue mass was enhanced by about $40 \%$ and significant amounts of triacylglycerol were stored not only in hypertrophic adipocytes but also in liver and muscle. In comparison, an energy-rich synthetic high-carbohydrate diet induced minimal changes in body weight, fat deposi- tion and regulation of blood glucose and lipids compared with control mice fed standard laboratory chow. This observation serves to illustrate well the clear-cut detrimental metabolic effects of diets deriving energy from fat as opposed to complex carbohydrates. Administration of $\left(\mathrm{Pro}^{3}\right)$ GIP had no effect on the phenotype in the mice fed the high-carbohydrate diet.

Consistent with involvement of GIP in mediating the detrimental effects of high-fat feeding, daily GIP receptor antagonism using $\left(\mathrm{Pro}^{3}\right)$ GIP had quite remarkable effects in protecting mice from consequences of either of the synthetic and cafeteria high-fat diets. Thus although administration of $\left(\mathrm{Pro}^{3}\right) \mathrm{GIP}$ during free access to high-fat diets did not affect energy intake, the excessive body weight gain was substantially decreased or even totally blocked following cafeteria feeding. In both groups, this was associated with decreases in adipose tissue mass, and adipocyte size was also remarkably decreased in the highfat group. These animals also exhibited improved liver morphology and lesser deposition of triacylglycerol in adipose tissue, muscle and liver. These data point to crucial effects of GIP antagonism in enhancing energy expenditure in situations of high-fat feeding. Such a view is reinforced by studies conducted using GIP receptor knockout mice [2, 31]. Absence of similar actions following high-carbohydrate feeding in the present study is probably a reflection of the different metabolism of sugars and the fact that they are much weaker stimulators of GIP secretion and do not induce prominent changes in intestinal and circulating GIP [10]. Nevertheless, the fact that the carbohydrate and energy content of this diet were only 17 and $45 \%$ greater than normal chow should not be overlooked.

Although an increase of energy expenditure might also reflect enhanced locomotor activity as suggested here and elsewhere [31], this is unlikely to be the only mechanism underlying weight loss in mice with ablated GIP signalling. Furthermore, overexpression of GIP in transgenic mice has actually been linked to enhanced locomotor activity [32]. Accordingly, we believe that blockade of metabolic actions of GIP consequent to increased dietary fat intake is very largely responsible for energy dissipation. Thus, blockade of GIP receptor signalling can be expected to counter lipogenesis, promote lipolysis and importantly direct circulating lipids towards liver and skeletal muscle where they are used as a preferential energy substrate for fat oxidation [2]. Although mice in the high-fat group that were treated with $\left(\mathrm{Pro}^{3}\right)$ GIP continued to display hyperinsulinaemia, the subtle decrements in acute insulin secretion might also contribute to decreased fat accumulation. These various actions could explain the observed weight-reducing effects of $\left(\mathrm{Pro}^{3}\right) \mathrm{GIP}$, which are essentially similar to those observed in GIP receptor knockout mice [2]. The latter animals also exhibited a significant reduction 
Fig. 7 a Effects of daily (Pro ${ }^{3}$ ) GIP administration on combined adipose tissue mass in mice fed high-fat, cafeteria and highcarbohydrate diets. Parameters were measured after daily treatment with $\left(\mathrm{Pro}^{3}\right)$ GIP $(25 \mathrm{nmol} /$ $\mathrm{kg}$ body weight) or saline for 16 weeks. Open bars, control saline; filled black bars, high fat; diagonal striped bars, high fat $+\left(\mathrm{Pro}^{3}\right) \mathrm{GIP}$; filled grey bars, cafeteria; horizontal striped bars, cafeteria $+\left(\mathrm{Pro}^{3}\right) \mathrm{GIP}$; vertical striped bars, high carbohydrate; hatched bars, carbohydrate $+\left(\mathrm{Pro}^{3}\right)$ GIP. Effects of $\left(\mathrm{Pro}^{3}\right)$ GIP on white adipose tissue morphology (b), tissue triacylglycerol content (c) and liver morphology (d) in mice fed a high-fat diet. Values are means \pm SEM for nine mice. $* * p<0.01$ and $* * * p<0.001$ compared with control group; ${ }^{\Delta} p<0.05,{ }^{\Delta \Delta} p<0.01$ and $\Delta \Delta \Delta p<0.001$ compared with $\left(\right.$ Pro $\left.^{3}\right)$ GIP-treated group. Representative images are original magnification $\times 20$ a

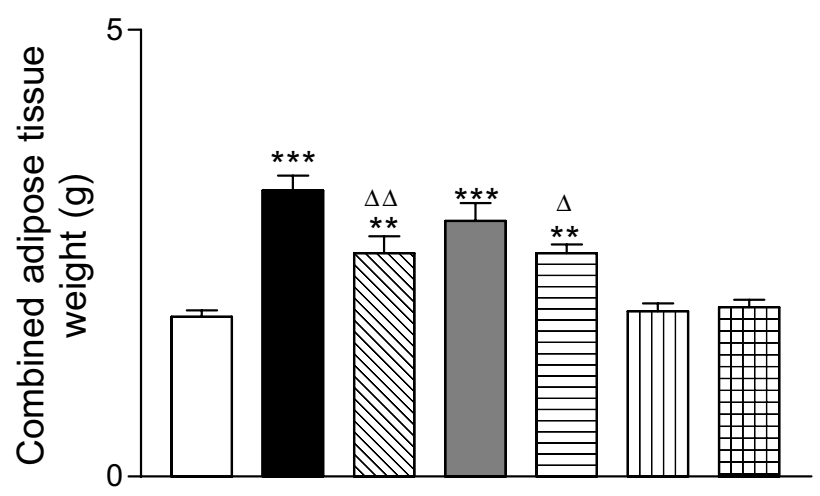

b
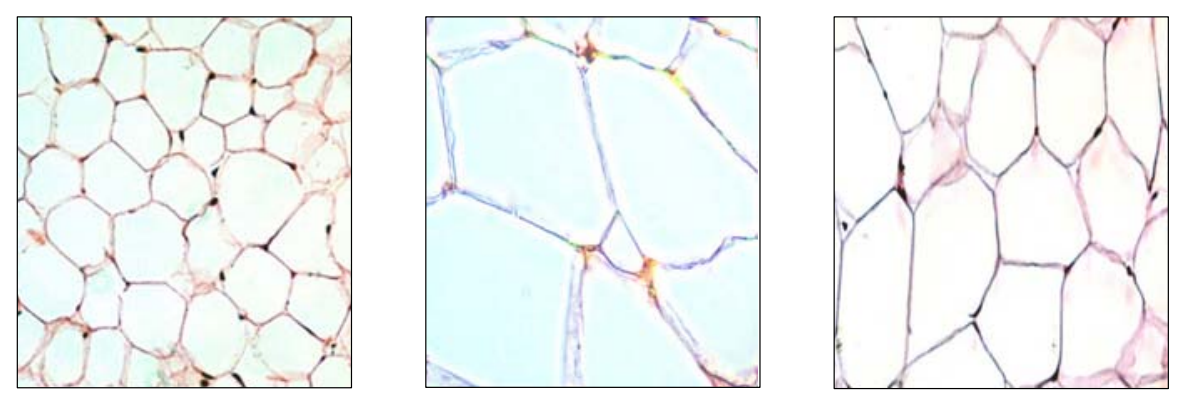

C
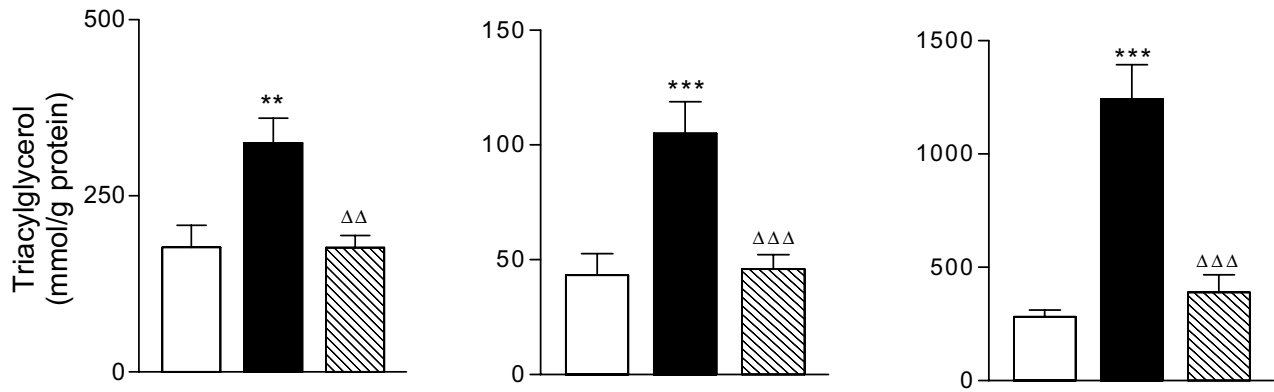

d

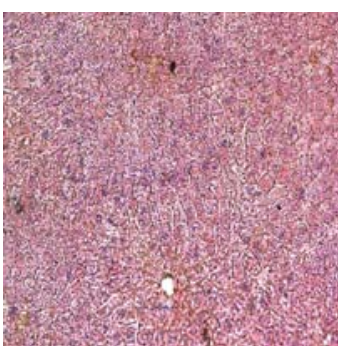

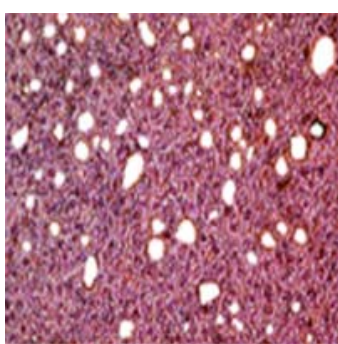

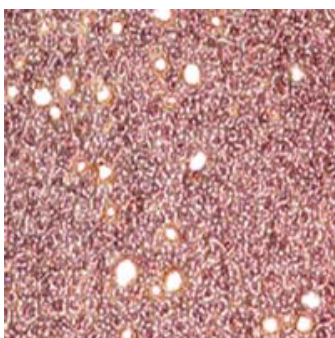

of respiratory quotient during the light phase without change in oxygen consumption, indicating utilisation of fat as energy substrate rather than its accumulation in adipocytes. In addition, genetic ablation of the GIP receptor under situations of diminished insulin action has been shown to promote energy dissipation in liver, both by increasing hepatic fatty acid uptake through stimulating CD36 expression and by uncoupling nutrient oxidation to ATP generation through increasing uncoupling protein-2 [33]. In skeletal muscle, ablation of GIP also increased both the expression and activity of the enzyme 3-hydroxyacyl-CoA dehydrogenase, which promotes fat oxidation. 
In the present study, protection from high fat-induced obesity by $\left(\mathrm{Pro}^{3}\right)$ GIP was accompanied by similar protection from development of hyperglycaemia, insulin resistance, glucose intolerance and hyperlipidaemia. Total cholesterol concentrations were also decreased in the high-fat group. Notwithstanding the obvious benefit of decreased adiposity, various mechanisms are likely to underlie the beneficial action of GIP receptor blockade. This is clearly indicated by similar desirable metabolic effects of $\left(\mathrm{Pro}^{3}\right) \mathrm{GIP}$ in $\mathrm{ob} / \mathrm{ob}$ mice that were not accompanied by any change in body weight [4, 24]. These mechanisms are likely to centre around reversal of the biochemical abnormalities through which high fat intake and obesity cause insulin resistance [34]. This action might result from decreased glucose production and/or increased glucose uptake and metabolism in liver, muscle or adipose tissue. Additionally, the observed changes in fat accumulation and metabolism of lipids at these sites will be involved. Thus, it is well known that inhibition of fat oxidation is correlated with increased intracellular triacylglycerol and interference of insulin signalling and decreased insulin action [35-37]. $\left(\mathrm{Pro}^{3}\right) \mathrm{GIP}$ can be expected to reverse such effects together with related adverse effects on the glucosefatty acid cycle. The present study did not reveal appreciable changes in circulating glucagon, adiponectin or resistin following GIP receptor blockade. This contrasts with the idea that GIP might upregulate circulating resistin concentrations [31]. Corticosterone was decreased, suggesting that inhibition of circulating or local production of corticosterone might be involved, as this promotes hepatic gluconeogenesis and antagonises insulin-stimulated glucose uptake in both skeletal muscle and adipose tissue [38].

The retention of beta cell function and insulin secretion in $\left(\right.$ Pro $\left.^{3}\right)$ GIP-treated mice fed high-fat diets can be explained in terms of beta cell sparing due to decreased insulin demand as a result of improved insulin sensitivity, lower prevailing glucose levels and alleviation of chronic dietinduced GIP receptor activation. Glucagon-like peptide (GLP)-1 has many beneficial actions on beta cell function and we have some evidence that a compensatory enhancement of GLP-1 function, as observed in GIP receptor knockout mice [39], may contribute. Thus, although circulating GLP-1 was unchanged in $o b / o b$ mice treated with $\left(\right.$ Pro $\left.^{3}\right)$ GIP, administration of the GLP-1 antagonist exendin(9-39) had detrimental effects [40]. Neither does there appear to be a distinguishable role for glucagon inhibition, as circulating concentrations were unchanged by $\left(\mathrm{Pro}^{3}\right) \mathrm{GIP}$ in the present study. Absence of beta cell glucose and lipid toxicity, together with a decrease in adiposity, will contribute to maintaining effective insulin secretory function and glucose homeostasis in $\left(\mathrm{Pro}^{3}\right)$ GIP-treated mice fed a high-fat diet.

In conclusion, GIP receptor blockade using $\left(\mathrm{Pro}^{3}\right)$ GIP acts in both diet-induced and genetic obesity-diabetes $[4,24]$ to decrease insulin resistance, improve glucose tolerance and enhance beta cell function. As shown in the present study, longer-term treatment also protects from obesity and associated abnormalities of circulating and tissue lipids induced by high-fat diets. There are very strong parallels between these effects and those of GIP receptor knockout $o b / o b$ mice [2] and surgical bypass of GIP-secreting $\mathrm{K}$ cells in humans undergoing Roux-en-Y surgery for the treatment of gross obesity [41-44]. These various observations in diet-induced models and man suggest that GIP receptor antagonists, such as $\left(\mathrm{Pro}^{3}\right)$ GIP, represent an exciting class of future drug for the treatment of obesity and alleviation of diabetes [45].

Acknowledgements These studies were supported by a Project Grant from Diabetes UK and University of Ulster Research Strategy Funding.

Duality of interest V. A. Gault, N. Irwin and P. R. Flatt are shareholders in Diabetica.

\section{References}

1. Haines L, Wan KC, Lynn R, Barrett TG, Shield JP (2007) Rising incidence of type 2 diabetes in children in the U.K. Diabetes Care 30:1097-1101

2. Miyawaki K, Yamada Y, Ban N et al (2002) Inhibition of gastric inhibitory polypeptide signaling prevents obesity. Nat Med 8:738742

3. Gault VA, O'Harte FP, Flatt PR (2003) Glucose-dependent insulinotropic polypeptide (GIP): anti-diabetic and anti-obesity potential? Neuropeptides 37:253-263

4. Gault VA, Irwin N, Green BD et al (2005) Chemical ablation of gastric inhibitory polypeptide receptor action by daily $\left(\right.$ Pro $\left.^{3}\right)$ GIP administration improves glucose tolerance and ameliorates insulin resistance and abnormalities of islet structure in obesity-related diabetes. Diabetes 54:2436-2446

5. Yamada Y, Miyawaki K, Tsukiyama K, Harada N, Yamada C, Seino Y (2006) Pancreatic and extrapancreatic effects of gastric inhibitory polypeptide. Diabetes 55(Suppl 2):S86-S91

6. Kieffer TJ (2003) GIP or not GIP? That is the question. Trends Pharmacol Sci 24:110-112

7. Yamada Y, Seino Y (2004) Physiology of GIP — a lesson from GIP receptor knockout mice. Horm Metab Res 36:771-774

8. Drucker DJ (2007) The role of gut hormones in glucose homeostasis. J Clin Invest 117:24-32

9. Ross SA, Dupre J (1978) Effects of ingestion of triglyceride or galactose on secretion of gastric inhibitory polypeptide and on responses to intravenous glucose in normal and diabetic subjects. Diabetes 27:327-333

10. Bailey CJ, Flatt PR, Kwasowski P, Powell CJ, Marks V (1986) Immunoreactive gastric inhibitory polypeptide and $\mathrm{K}$ cell hyperplasia in obese hyperglycaemic $(o b / o b)$ mice fed high fat and high carbohydrate cafeteria diets. Acta Endocrinol (Copenh) 112:224-229

11. Flatt PR, Bailey CJ, Kwasowski P, Swanston-Flatt SK, Marks V (1983) Abnormalities of GIP in spontaneous syndromes of obesity and diabetes in mice. Diabetes 32:433-435

12. Flatt PR, Bailey CJ, Kwasowski P, Swanston-Flatt SK (1990) Effects of diets rich in sucrose, coconut fat and safflowerseed oil on the development of the obese hyperglycaemic (ob/ob) syndrome in mice. Diabetes Res 13:23-28 
13. Ponter AA, Salter DN, Morgan LM, Flatt PR (1991) The effect of energy source and feeding level on the hormones of the entero-insular axis and plasma glucose in the growing pig. Br J Nutr 66:187-197

14. Flatt PR, Bailey CJ, Kwasowski P, Page T, Marks V (1984) Plasma immunoreactive gastric inhibitory polypeptide in obese hyperglycaemic $(o b / o b)$ mice. J Endocrinol 101:249-256

15. Creutzfeldt W, Ebert R, Willms B, Frerichs H, Brown JC (1978) Gastric inhibitory polypeptide (GIP) and insulin in obesity: increased response to stimulation and defective feedback control of serum levels. Diabetologia 14:15-24

16. Salera M, Giacomoni P, Pironi L et al (1982) Gastric inhibitory polypeptide release after oral glucose: relationship to glucose intolerance, diabetes mellitus, and obesity. J Clin Endocrinol Metab 55:329-336

17. Yip RG, Boylan MO, Kieffer TJ, Wolfe MM (1998) Functional GIP receptors are present on adipocytes. Endocrinology 139:4004-4007

18. Eckel RH, Fujimoto WY, Brunzell JD (1979) Gastric inhibitory polypeptide enhanced lipoprotein activity in cultured preadipocytes. Diabetes 28:1141-1142

19. Oben J, Morgan LM, Fletcher J, Marks V (1991) Effect of the entero-pancreatic hormones, gastric inhibitory polypeptide and glucagon-like polypeptide-1(7-36)amide, on fatty acid synthesis in explants of rat adipose tissue. J Endocrinol 130:267-272

20. Knapper JM, Puddicombe SM, Morgan LM, Fletcher JM (1995) Investigations into the actions of glucose-dependent insulinotropic polypeptide and glucagon-like peptide-1(7-36) on lipoprotein lipase activity in explants of rat tissue. J Nutr 125:183-188

21. Kim SJ, Nian C, McIntosh CH (2007) Activation of lipoprotein lipase by glucose-dependent insulinotropic polypeptide in adipocytes: a role for a protein kinase B, LKB1 and AMP-activated protein kinase cascade. J Biol Chem 282:8557-8567

22. Dupre J, Greenidge N, McDonald TJ, Ross SA, Rubinstein D (1976) Inhibition of actions of glucagon in adipocytes by gastric inhibitory polypeptide. Metabolism 25:1197-1199

23. Getty-Kaushik L, Song DH, Boylan MO, Corkery BE, Wolfe MM (2006) Glucose-dependent insulinotropic polypeptide modulates adipocyte lipolysis and reesterification. Obesity 14:1124-1131

24. Irwin N, McClean PL, O'Harte FPM, Gault VA, Harriott P, Flatt PR (2007) Early administration of the glucose-dependent insulinotropic polypeptide receptor antagonist $\left(\right.$ Pro $\left.^{3}\right)$ GIP prevents the development of diabetes and related metabolic abnormalities associated with genetically inherited obesity in $o b / o b$ mice. Diabetologia DOI 10.1007/s00125-007-0692-2

25. Holscher C, Schmid S, Pilz PK, Sansig G, van der Putten H, Plappert CF (2004) Lack of the metabotropic glutamate receptor subtype 7 selectively impairs short-term working memory but not long-term memory. Behav Brain Res 154:473-481

26. Stevens JF (1971) Determination of glucose by an automatic analyzer. Clin Chim Acta 32:199-201

27. Flatt PR, Bailey CJ (1981) Abnormal plasma glucose and insulin responses in heterozygous lean $(o b /+)$ mice. Diabetologia 20:573-577

28. Carr TP, Andresen CJ, Rudel LL (1993) Enzymatic determination of triglyceride, free cholesterol, and total cholesterol in tissue lipid extracts. Clin Biochem 26:39-42
29. Burington RS (1973) Handbook of mathematical tables and formulae. McGraw-Hill, New York

30. Flatt PR, Bailey CJ, Kwasowski P, Swanston-Flatt SK, Marks V (1985) Glucoregulatory effects of cafeteria feeding and diet restriction in genetically obese hyperglycaemic $(o b / o b)$ mice. Nutr Rep Int 32:847-854

31. Hansotia T, Maida A, Flock G et al (2007) Extrapancreatic incretin receptors modulate glucose homeostasis, body weight, and energy expenditure. J Clin Invest 117:143-152

32. Ding KH, Zhong Q, Xie D et al (2006) Effects of glucose-dependent insulinotropic polypeptide on behaviour. Peptides 27:2750-2755

33. Zhou H, Yamada Y, Tsukiyama K et al (2005) Gastric inhibitory polypeptide modulates adiposity and fat oxidation under diminished insulin action. Biochem Biophys Res Commun 335:937-942

34. Yki-Jarvinen H (2003) Insulin resistance in type 2 diabetes. In: Pickup JC, Williams G (eds) Textbook of diabetes, 3rd edn. Blackwell Science, Oxford, pp 22.1-22.19

35. Goodpaster BH, He J, Watkins S, Kelley DE (2001) Skeletal muscle lipid content and insulin resistance: evidence for a paradox in endurance-trained athletes. J Clin Endocrinol Metab 86:5755-5761

36. Shulman GI (2000) Cellular mechanisms of insulin resistance. J Clin Invest 106:171-176

37. Ryysy L, Hakkinen AM, Goto T et al (2000) Hepatic fat content and insulin action on free fatty acids and glucose metabolism rather than insulin absorption are associated with insulin requirements during insulin therapy in type 2 diabetic patients. Diabetes 49:749-758

38. Donckier JE (2003) Endocrine diseases and diabetes. In: Pickup JC, Williams G (eds) Textbook of diabetes, 3rd edn. Blackwell Science, Oxford, pp 27.1-27.25

39. Pederson RA, Satkunarajah M, McIntosh CH et al (1998) Enhanced glucose-dependent insulinotropic polypeptide secretion and insulinotropic action in glucagon-like peptide 1 receptor -/mice. Diabetes 47:1046-1052

40. Parker JC, Irwin N, Lavery KS et al (2007) Metabolic effects of subchronic ablation of the incretin receptors by daily administration of $\left(\right.$ Pro $\left.^{3}\right)$ GIP and exendin(9-39)amide in obese diabetic $(o b / o b)$ mice. Biol Chem 388:221-226

41. Guidone C, Manco M, Valera-Mora E et al (2006) Mechanisms of recovery from type 2 diabetes after malabsorptive bariatric surgery. Diabetes 55:2025-2031

42. Mari A, Manco M, Guidone C et al (2006) Restoration of normal glucose tolerance in severely obese patients after bilio-pancreatic diversion: role of insulin sensitivity and beta cell function. Diabetologia 49:2136-2143

43. Clements RH, Gonzalez QH, Long CI, Wittert G, Laws HL (2004) Hormonal changes after Roux-en Y gastric bypass for morbid obesity and the control of type II diabetes mellitus. Am Surg 70:1-5

44. Rubino F, Gagner M, Gentileschi P et al (2004) The early effect of the Roux-en-Y gastric bypass on hormones involved in body weight regulation and glucose metabolism. Ann Surg 240:236-242

45. Flatt PR (2007) Effective surgical treatment of obesity may be mediated by ablation of the lipogenic gut hormone gastric inhibitory polypeptide (GIP): evidence and clinical opportunity for development of new obesity-diabetes drugs? Diab Vasc Dis Res (in press) 